chemical laws of the earth's atmosphere. He stresses the importance of understanding the principles behind the depleting ozone layer, air pollution, global warming, nuclear winter, acid rain, and ground-level pollution in order to provide solutions to these existing and to future environmental problems.

\section{Global Climate Change and Agricultural Production} (Fakhri Bazzaz and Wim Sombroek, Eds., 1997, 345 pp., \$115.00, hardbound, John Wiley \& Sons, ISBN 0-471-95763-1). To reflect the conclusion from the 1995 Intergovernmental Panel on Climate Change that "the balance of evidence suggests a discernible human influence on global climate," many scientists incorporated this theory into their studies of how climate change would affect agricultural production of crops and livestock. The chapters contained in this book were originally presented at the United Nations Environment Program's Expert Consultation, which was held at the Food and Agricultural Organization. The material contributed by 25 scientists covers the direct and indirect effects on agriculture at a regional level from anthropogenic climate change. Covered within the material are issues such as the $\mathrm{CO}_{2}$ fertilization effect; the adverse effect of elevated levels of UV-B radiation and ozone on plant growth and productivity and on livestock; and the effects of changing $\mathrm{CO}_{2}$, temperature, UV-B radiation, and ozone simultaneously on crop growth.

The Perfect Storm (Sebastian Junger, 1997, 227 pp., $\$ 23.95$, hardbound, W. W. Norton \& Company, ISBN 0-393-04016-X). Set in the fishing community of Gloucester, Massachusetts, this narrative incorporates fact with fiction in describing the plight of the fishing boat Andrea Gail. Deemed the "perfect storm" by a number of meteorologists, Junger describes the October 1991 storm, the gale in which the Andrea Gail disappeared, with scientific accuracy combined with the courage, terror, and awe experienced by those who were affected by the storm. In all, the book weaves together a story about the fishing industry, the science of storms, and candid accounts of the people whose lives the storm touched.

\title{
Publishers' Addresses
}

Agrometeorological Applications

Associates

B.P. 102

F-01213 Ferney-Voltair, France

Fax: 01133450408842

$$
\begin{gathered}
\text { Cambridge University Press } \\
40 \text { W. } 20 \text { St. } \\
\text { New York, NY } 10011 \\
\text { Telephone: } 800-872-7423
\end{gathered}
$$

\section{Chip Taylor Communications \\ 15 Spollett Dr. \\ Derry, $\mathrm{NH} 03038$ \\ Telephone: 800-876-2447}

\section{Kent State University Press \\ P.O. Box 5190 \\ Kent, $\mathrm{OH} 44242$ \\ Telephone: 330-672-7913}

National Geographic Society

1145 17th St., NW

Washington, DC 20036

Telephone: 800-447-0647

\section{W. W. Norton \& Company 500 Fifth Ave. \\ New York, NY 10110 \\ Telephone: 800-233-4830}

\section{Spectroradiometry Consulting \\ P.O. Box 2747 \\ La Plata, MD 20646 \\ Telephone: 301-934-6364}

Taylor \& Francis

1900 Frost Rd., Suite 101

Bristol, PA 19007

Telephone: 800-821-8312

Visible Ink Press

835 Penobscot Bldg.

645 Griswold St.

Detroit, MI 48226

Telephone: 800-776-6265

John Wiley \& Sons

1 Wiley Drive

Somerset, NJ 08875-1272

Telephone: 800-225-5945 